\title{
Discussion on the Reform of Accounting Teaching in Colleges and Universities Under the Student-Oriented Concept
}

\author{
Zhang Li
}

Guangzhou College of Technology and Business

Sanshui Campus, Fan-hu Development Zone, Leping Town, Sanshui District, Foshan, Guangdong

Abstract. Student-oriented is one of the key concepts in accounting teaching in colleges and universities. It requires teachers to take students as the center of the classroom to ensure that all activities are carried out based on their actual learning ability. However, as far as the implementation of the text concept of students is concerned, due to the influence of traditional teaching concepts, most teachers still regard teachers as classroom centers, which affects the quality of accounting teaching. Therefore, this article mainly discusses the reform of accounting teaching under the concept of "student-oriented", hoping to help teaching.

Under the traditional "teacher-based" teaching concept and mode, college teachers pay more attention to the transfer and assessment of relevant theoretical knowledge to students when teaching ignores the importance of curriculum practical operation. The introduction of the "student-oriented" teaching concept can help teachers fully recognize the differences and advantages of different students, which is conducive to fully mobilize students' learning enthusiasm and improve effectiveness.

Keywords: student-oriented, accounting teaching, teaching reform

\section{Adjust teaching goals by student-oriented}

To carry out the teaching reform project of college accounting courses more scientifically and reasonably, the most critical point is to adjust and even reposition the teaching objectives of college accounting courses from the perspective of students and fully integrate the needs of the times[1]. The establishment of teaching objectives is not only a prerequisite for carrying out the reform of accounting teaching, but also a key factor affecting the reform of accounting. Therefore, only by fully combining the pace of the development of the times and understanding and respecting the advantages and characteristics of different students, can the teaching goal be gradually transformed into training of complex financial talents with professional accounting ability to be closer to the current society and the market for student requirements to meet the display needs of current employment.

In adjusting the teaching goals, in order to better highlight the student-centered and respect the individuality of students and give full play to each student's greatest advantage, the following methods can be adopted when formulating the teaching goals and plans of accounting courses. First of all, at the current stage, many students did not have a complete and scientific understanding of accounting before choosing and joining the discipline of accounting. They did not have a clear understanding of their future learning plans and long-term development plans. At this time, college teachers should focus on basic theoretical knowledge and science, which not only includes basic accounting theory knowledge, but also the current development of the accounting industry at this stage and in the next ten years for college accounting. The specific requirements of professional talents and other contents allow students to have a more three-dimensional and multiple level understanding of the accounting discipline.

\section{Integrate teaching material and system by "student-oriented"}

Regardless of the course, the textbook is an important theoretical basis for teachers to conduct classroom teaching. The textbook has a key guiding role in the teaching of the subject, and with a decisive role in the final teaching effect and quality of the subject. Therefore, when implementing the student-oriented teaching concept, college teachers should integrate teaching materials with the students' learning ability and level, and take the classroom such as the improvement of students' comprehensive accounting literacy, accounting theory and practice, and basic accounting skills as the main object of explanation. Social practice is the main textbook. In addition, in terms of the integration of teaching materials, teachers need to recognize the importance of teaching materials integration, break the traditional clear thinking of disciplines, combine the knowledge of various subjects, and develop a teaching material integration plan that meets the needs of society and bring into play the role of integration of teaching materials to enhance the ability of college accounting students. And when implementing the integration of teaching materials, accounting teachers should also recognize the practicality of the integration of teaching materials, and create a practical platform for 
students in time to allow students to experience the usefulness of knowledge. It can stimulate students' interest in learning and improve students' practical ability.

\section{REFORM THE TRADITIONAL TEACHING MODE BASED ON "STUDENT-ORIENTED"}

Under the influence of traditional teaching concepts, college teachers often take themselves as the center of the classroom when teaching accounting, and require that all activities of students in the classroom must be teacher-centered in the classroom, and they cannot deviate from the teacher's teaching goals. Although this traditional teaching mode helps teachers to grasp the progress of classroom teaching, it has impeded the initiative and enthusiasm of students' knowledge of accounting and is not conducive to the learning of accounting knowledge. Therefore, in order to better carry out the teaching of accounting and achieve the effective improvement of teaching quality and effect, the most fundamental thing for all universities is to reform and innovate their teaching models and resolutely abandon the traditional teaching mode with accounting theory. Knowledge is the key teaching method. In the subsequent teaching process, the emphasis on the independent analysis of problems and the cultivation of problem-solving abilities are gradually increased. It involves the reform and innovation of specific teaching modes. On the one hand, they must be good at drawing on the advanced teaching concepts and modes adopted by other universities at home and abroad in the accounting discipline; on the other hand, they need to fully integrate the actual situation of each university. Teachers must respect each student's subject status both in the formulation of teaching plans and objectives in the arrangement of textbook and curriculum systems and in the evaluation of subsequent teaching results. This course is student-oriented and focuses on the training and cultivation of students' comprehensive practical ability and actual accounting.

Taking the assignment of subject as an example, whether it is a traditional education mode or a new type of education, assignments are an indispensable link, which is determined by the importance of the assignments. After all, assignments are both to consolidate and deepen classroom. The key approach is also a major way to help teachers keep abreast of student learning. Therefore, in the process of reforming the teaching mode of accounting in colleges and universities, teachers must also strengthen the reform of the layout of homework[2]. For the more theoretical knowledge in accounting, teachers can choose to investigate in the form of small papers. Breaking the fixed test paper examination form to strengthen students' in-depth understanding of relevant knowledge. For practicality of relatively strong knowledge, teachers can use a combination of practice simulation and case analysis and more classroom discussions to help students grasp the relevant in all aspects. Teachers can fully expand the students' thinking mode and strengthen comprehensive level of students.

\section{STUDENT-ORIENTED REFORM OF TRADITIONAL ASSESSMENT METHODS}

In the traditional assessment mode, teachers often use the student's test results as the only assessment indicator. When the student's test score is high, the teacher praises the student, but when the student's academic performance is low, the teacher criticizes the student. Although this assessment mode can promote students' knowledge learning, it may hurt the learning confidence of students with unsatisfactory test results, which is not conducive to students' further knowledge learning. Under the "student-oriented" teaching mode, the assessment mode adopted by teachers is often a combination of students' daily performance, classroom learning participation, and final test results, and then the final results of the students are obtained. The assessment method can effectively stimulate students' enthusiasm for learning and ensure their confidence in learning. Therefore, in the new teaching environment, teachers should strictly implement the "student-oriented" assessment requirements, innovate the classroom teaching mode of accounting, and change the evaluation disadvantages of the traditional assessment mode in a timely manner.

Taking subject assessment as an example, teachers can tell students that the assessment method for this semester is to use students' classroom performance, participation in classroom activities, application of accounting and final exam results as comprehensive assessment indicators and score[3]. The standard is displayed to students through a large multimedia screen. This allows students to determine the assessment method for the new semester and stimulates students' motivation to learn accounting. Secondly, when designing the assessment indicators, teachers should ensure that the test scores is equivalent to students' daily performance. It can ensure that students actively implement the teacher's requirements in daily life and thus improve the learning ability of students. Finally, teachers should also pay attention to the differences of students in the assessment and evaluation. This is because class students have different learning abilities. Some students have strong learning abilities and can efficiently complete teacher teaching tasks, but some students have poor learning abilities. They are unable to complete the teacher's requirements with quality and quantity. If the teacher follows a consistent assessment and evaluation method, it may affect the learning confidence of some students who have weak learning abilities but are actively motivated. Therefore, when implementing the "student-oriented" teaching requirements, accounting teachers need to set assessment indicators that meet the students' own strengths based on different students' learning abilities, and encourage students in a timely manner when students complete the teachers' assessment indicators to increase knowledge of accounting and confidence. Through the adoption of this "student-oriented" 
assessment mode, students' interest in accounting can be cultivated and their ability to learn accounting can be effectively improved.

\section{CONCLUSION}

At present, major colleges and universities have begun to gradually implement student-oriented teaching requirements in the reform of accounting teaching. However, there are still problems such as teachers not understanding the importance of the "student-oriented" teaching philosophy and the lack of student-oriented teaching methods. This affects the role of the "student-oriented" teaching mode. Therefore, in the later accounting teaching, college teachers must innovate teaching plans and strictly implement the teaching requirements. It is firmly believed that when college teachers effectively implement the student-oriented concept into teaching, they can effectively improve students' learning enthusiasm and cultivate more applied accounting talents for the society.

\section{REFERENCES}

[1] Zhao Juming, Gao Xiaohui. 2019. Focusing on Learning Affects: Building a Unified Teaching Quality Guarantee System for The Whole College — the Fifth Study of "Student-centered" Undergraduate Teaching Reform in the United States [J]. Research in Higher Engineering Education, (3): 5 -20 .

[2] Zhao Juming. 2019. Helping Learning: Learning Environment and Educational Technology_the Fourth Study of "Student-centered" Undergraduate Teaching Reform in the United States [J]. Research in Higher Engineering Education, (2).

[3] Zhou Yanyan. 2018. Research on the Five-year Higher Vocational Accounting Teaching Reform under the Student-oriented Concept [J]. College Entrance Examination, (36). 